ГЕРНИОПЛАСТИКА ПРИ БОЛЬШИХ И ГИГАНТСКИХ ХИАТАЛЬНЫХ ГРЫЖАХ

\author{
Розенфельд Игорь Игоревич \\ кандидат медииинских наук, доцент \\ ФГБОУ ВО Тверской ГМУ Минздрава России, \\ 2. Тверь
}

\title{
HERNIOPLASTY FOR LARGE AND GIANT CHIATAL HERNIA
}

\author{
Rosenfeld Igor \\ Candidate of medical Sciences, associate professor \\ Medical University of the Ministry of Health, Tver \\ DOI: 10.31618/nas.2413-5291.2020.2.60.307
}

\section{АННОТАЦИЯ}

Предложен оригинальный способ двухслойной аллогерниопластики медицинским биокарбоном с фиксацией сетки позади ножек диафрагмы в комбинации с крурорафией.

В исследовании приняло участие 124 пациента, из них 66 человек контрольной группы I (пластика по традиционному методу) и 58 человек - исследовательская группа II, им выполняли оригинальный фиксационный способ. Критерии включения в исследование: возраст старше 18 лет, отсутствие соматической патологии, информированное согласие пациента. Результаты оценивались в рамках пилотного исследования по шкале «VAS».

\section{ABSTRACT}

An original method of two-layer allohernioplasty with medical biocarbon with mesh fixation behind the legs of the diaphragm in combination with cruraphy is proposed.

The study involved 124 patients, including 66 people from the control group I (plastic surgery according to the traditional method) and 58 people from the research group им, they underwent the original fixation method. Study inclusion criteria: age over 18 years, absence of somatic pathology, informed consent of the patient. The results were assessed in a pilot study on the VAS scale.

Ключевые слова: герниопластика; большие грыжи пищеводного отверстия диафрагмы, гигантские грыжи пищеводного отверстия диафрагмы.

Keywords: hernioplasty; large hiatal hernia, giant hiatal hernia.

Вопрос фиксации имплантата крайне актуален. По данным Sajid M. S. отсутствие фиксации не повышает риск его миграции или возникновения рецидива, но данная апробация методики при грыжах пищеводного отверстия диафрагмы (ГПОД) не проведена. В работе Tam K. W. говорится, что выполнение хирургической операции без фиксации сетки не влечёт к повышению рецидивов $[1,2,3]$.

Для предупреждения рецидивов рекомендуется использовать сетку размером $10 \times 15 \mathrm{~cm}$, при размерах грыжи более $4 \mathrm{~cm}$ имплантировать сетку с большими параметрами, например, $12 \times 19$ см $[4,5]$.

Считается что жёсткие полипропиленовые и композитные материалы - самые надёжные в плане профилактики рецидивов, а сетчатые имплантаты дают осложнения с частотой 2-25\%. Биологические имплантаты наоборот, хотя и дают минимальный процент осложнений, но частота анатомических рецидивов (АР) при их использовании $-10-50 \%, \quad$ что является неприемлемым [6].

Цель исследования: описание приемуществ концепции методики двухслойной аллогерниопластики частично рассасывающимся облегчённым сетчатым имплантатом.

Материалы и методы: Операцией выбора при гастроэзофагеальной рефлюксной болезни, ассоциированной с ГПОД, признана пластика пищеводного отверстия диафрагмы фундопликация по Ниссену, эффективность которой составляет 86-95\%. Наиболее часто используются варианты фиксации: фиксация сетки поверх ножек диафрагмы после крурорафии и фиксация краёв сетки к ножкам диафрагмы без крурорафии [7].

Предложен

оригинальный способ двухслойной аллогерниопластики медицинским биокарбоном с фиксацией сетки позади ножек диафрагмы в комбинации с крурорафией. Облегчённый имплантат состоит из двух слоёв: первый частично рассасывается, второй - биокарбоновая плёнка на основе карбита. Структура позволяет снизить риск АР, так как при классической методике может формироваться грубая рубцовая ткань [8].

В исследовании приняло участие 124 пациента, из них 66 человек контрольной группы I (пластика по традиционному методу) и 58 человек - исследовательская группа II, им выполняли оригинальный фиксационный способ. Критерии включения в исследование: возраст старше 18 лет, отсутствие соматической патологии, информированное согласие пациента. Результаты оценивались в рамках пилотного исследования по шкале «VAS». Пациенты опрашивались перед операцией, на 3-й день после операции и через 1 год. Критический уровень значимости был менее 0,05 по Пирсону.

Результаты представлена

и обсуждения: впервые оригинальная концепция 
аллогерниопластики для лечения больших и гигантских ГПОД. Предложенная методика основана на клинических рекомендациях «SAGES».

По контрольной группе необходимо отметить, что болевой синдром отмечался у 53,3\% пациентов. У 7 больных степень интенсивности боли по визуальной аналоговой шкале составила 1-3 балла, один отмечал умеренную боль по аналоговой шкале в 4-6 балла, у одного пациента из группы с фиксированным протезом наблюдался сильный болевой синдром (7-10 баллов).

Болевой синдром в экспериментальной группе пациентов значимо уменьшился в послеоперационном периоде, по визуальной аналоговой шкале составил 1-3 балла у подгруппы Б. Ни у одного из пациентов основной группы не отмечалось сильной хронической боли.

Выводы:

1. Выявлена проблема в хирургическом лечении ГПОД, проявляющаяся в высоком риске возникновения болевого синдрома и риска рецидивов при ГПОД.

2. Доказана перспектива оптимизации хирургического метода для профилактики АР на основе оригинального способа аллогерниопластики.

3. Получены положительные клинические результаты новой методики по болевому синдрому.

\section{Литература:}

1. Баулин А. А. От оперативного лечения грыжи пищеводного отверстия диафрагмы до оперативного лечения гастроэзофагеальной рефлюксной болезни / А. А. Баулин, В. А. Баулин, О. А. Баулина,

В. А. Стародубцев // Хирургия. - 2017. - С. 3133.

2. Грубник В. В. Методы лапароскопической фундопликации / В. В. Грубник, В.В.Ильяшенко, А. В. Грубник, А. В. Малиновский // Клиническая хирургия. - 2017. - Т. 5, № 6. - С. 23-24.

3. Розенфельд И. И. Отдалённые результаты лапароскопической пластики хиатальных грыж / И. И. Розенфельд // Тезисы VI Всероссийской межвузовской научно- практической конференции молодых учёных с международным участием «Молодёжь и медицинская наука». - Тверь: ФГБОУ ВО Тверской ГМУ Минздрава России. Совет молодых учёных и студентов. - 2018. - С. 56-57.

4. Розенфельд И. И. Классификация негативных результатов лапароскопических операций при грыжах пищеводного отверстия диафрагмы / И. И. Розенфельд,

В. А. Акопян // Материалы XII Международной научно-практической конференции и студентов и молодых

«Молодежь - практическому учёных-медиков здравоохранению». - Тверь: ФГБОУ ВО Тверской ГМУ Минздрава России. Совет молодых учёных и студентов. - 2018. - С. 856-858.

5. Розенфельд И. И. Лапароскопическая пластика при больших и гигантских грыжах пищеводного отверстия диафрагмы / И. И. Розенфельд, Д. Л. Чиликина // Материалы Международного молодёжного форума посвященного 80 -летнему юбилею Ставропольского государственного медицинского университета «Неделя науки 2018». - Ставрополь: ФГБОУ ВО Ставропольский ГМУ Минздрава России. - 2018. - С. 408-409.

6. Розенфельд И. И. Основные проблемы, возникающие при пластике грыж пищеводного отверстия диафрагмы / И. И. Розенфельд, Д. Л. Чиликина // Материалы Международного молодёжного форума посвященного 80-летнему юбилею Ставропольского государственного медицинского университета «Неделя науки 2018». - Ставрополь: ФГБОУ ВО Ставропольский ГМУ Минздрава России. - 2018. - С. 409-411.

7. Розенфельд И. И. Оценка результатов использования сетчатых имплантатов при аллопластике грыж пищеводного отверстия диафрагмы / И. И. Розенфельд, Д. Л. Чиликина // Исследования и практика в медицине. - 2018. - Т. 5, № 4. - С. 82-90.

8. Bittner R. Guidelines for laparoscopic (TAPP) and endoscopic (TEP) treatment of inguinal hernia (International endohernia society [IEHS]) / R. Bittner, E. Arregui, T. Bisgaard et al. // Surgical Endoscopy. 2016. - № 25. - P. 2773-2843. 